\title{
ALLIANCES, COALITIONS AND THE WEAKENING OF THE PARTY SYSTEM IN MALAWI
}

\section{Samson Lembani}

\author{
Samson Lembani has served as country director for the Konrad Adenauer Foundation \\ in Malawi since 2001 \\ e-mail: slembani@yahoo.com
}

\begin{abstract}
In nascent democracies, like that in Malawi, with presidential regimes and plurality electoral systems, the emergence of fragmented political party systems is inevitable, characterised by ethnically polarised political behaviour, fragile institutions and minority governments. This ultimately leads to volatile and contentious legislative-executive relations, weak political party cohesion and the stagnation of democratic consolidation. Malawi's system inherently offers neither incentives for coalition formation nor mutual interdependence between the executive and the legislature. Hence, the latent conflicts, persistent governance crises, inertia and grinding executivelegislative confrontations. Among political actors and across minority regimes in Malawi recourse to coalition politics has not been embraced as an optimal democratic instrument and formal strategy for state governability since 1994. The Mutharika minority government (2004-2009), which was persistently frustrated by parliamentary paralysis, survived on the floorcrossing inducements of opposition legislators, extended judicial injunctions and the presidential prorogation of Parliament. In addition, the brief 'experiments' with government coalitions, 'collusions' and electoral alliances weakened cohesion within partner parties and hardly increased national cohesion, but promoted state governability and yielded marginal gains in democratic consolidation. This article argues that political institutions that are designed to encourage formal political coalitions and discourage floorcrossing (parliamentary systems and proportional electoral laws) serve to mitigate against state instability and enhance democratic consolidation.
\end{abstract}




\section{INTRODUCTION}

Although the terms alliance and coalition are, in practice, used interchangeably, especially among politicians themselves, existing literature treats them as similar but conceptually different. In attempting to retain this conceptual distinction it is essential to highlight what is common to the two and how, if at all, their constitutive elements separate them. It is imperative to mention that alliances and coalitions are phenomena associated with multiparty democracy and scenarios in which no single party can win an outright majority of legislative seats. Alliances and coalitions, therefore, facilitate the formation of a power-sharing government to ensure stable governance and increased legitimacy to govern and defuse executive-legislative tensions.

This article attempts to explore and explicate the causes of political party alliances and coalitions and how they affect (a) party systems, (b) democratic consolidation, (c) national cohesion and (d) state governability in Malawi.

The next section of the article contains a brief discussion of key theoretical aspects of this study, namely the definition and features of political alliances and coalitions. This is then linked to the conditions that rationalise the formation, maintenance and unmaking of alliances and coalitions. The section also presents an overview of the way in which floor crossing has substituted for formal coalitions in Malawi followed by a brief overview that seeks to explain whether specific institutional arrangements such as electoral systems, regime types and party systems promote or discourage political alliances and coalitions.

The second part presents Malawi's political profile, depicting the construction and status of its institutions and contextual conditions within which this discussion of alliances and coalitions is established. The third and fourth parts are fundamentally devoted to an empirical analysis of causes of party alliances and coalitions, systemic and political institutional considerations in party alliances and coalitions, and consequences for state governability, impact on the party system, democratic consolidation and national cohesion. Views expressed in this part are informed by documentary analysis of relevant publications, by the author's perspectives from his vast experience of working with political parties and previous research into coalitions in Malawi as well as by expert opinion. Short interviews were conducted in August and September 2013 on specific aspects with informants identified from the political parties that were most involved in coalitions in the country. The interviews were intended to solicit factual insights from the respondents' direct participation in alliances and coalitions. The final section summarises this discussion and concludes with reflections on future prospects for political alliances and coalitions in Malawi. 


\section{Defining alliances and coalitions}

One of the major expository theoretical models dealing with the notion of political coalitions is the seminal work of William Riker (1962), ${ }^{1}$ which, itself, built on the original thesis of Von Neumann \& Morgenstern (1953). This model introduced the zero-sum game theory to abstract an established and stable institutional context which hypothetically contextualised how and when political parties would combine forces and synergies and form coalitions from the perspective of western established democracies.

The thrust of Riker's book, which attracted as many fervent admirers as critics, depicts a politician as a rational actor seeking to maximise the prospect of winning and maintaining political power (Wyatt 1999, p 5). Hence he argued that, of necessity, political actors will tend to strategically form a minimal winning coalition to maximise their share of governmental power and the spoils or pay-offs of ministerial and sub-ministerial positions (Riker 1962). As his critics observe, the 'coalition size' assumption did not receive sufficient empirical validation and theoretical support. Real life coalition models predominantly feature minority government coalitions such as those formed in the Nordic countries (Sweden, Norway and Denmark) and / or those formed on the basis of common ideological identities, while those in Italy and France (Grofman 1996, pp 265, 267; Wyatt $1999, \mathrm{p} 5)$ are formed to structure and maximise harmony and predictability in policy choices.

There is an avalanche of definitions and typologies in literature on alliances and coalitions and it is beyond the intent and scope of this paper to exhaust them. A few will, however, suffice to show the vastness of the scholarship from which the working definition in this article is derived. Broadly, alliances and coalitions manifest in different forms and for varied reasons. They can be formal or informal, transient or lasting, in fragile or stable regimes, operate at national or sub-national level, at the political level or between and among civic groups. They may emerge to achieve altruistic (philanthropic or political) objectives or predatory interests in both democratic and autocratic governments (Leftwich \& Laws 2010, p 2). Alliances and coalitions are formed in all societies for the attainment of social, political or economic aspirations otherwise unachievable by an individual organisation, group or society (Leftwich \& Laws 2010, p 2). In the study of regime politics the analysis of coalition frameworks may be used to explain 'who sides with who, against who and over what' (Yashar 1997, p 15).

In advancing the argument that coalitions matter, Deborah Yashar defines them as 'alliances' or union arrangements among heterogeneous groups and social actors who wilfully sacrifice their divergent individual long-term interests for the 
sake of mobilising and realising 'intermediate collective goals'. Notably, Yashar's concept, which treats coalitions as synonymous with alliances, further asserts that coalition members can, for instance, organise joint election candidates without there necessarily being a common ideological identity among the constitutive partners. The cardinal aspect of this definition is the pursuit of and passion for intermediate, collective political goals, even among groups with distinctive ideological orientations.

This article adopts the definition of alliances and coalitions as the agreement to a joint cooperation and common agenda of a minimum of two political parties. Fundamental to the distinction between an alliance and a coalition is the timing and basis of the agreement. An alliance is formed prior to elections to 'maximise' votes, while a coalition refers to a post-election formation of political parties in Parliament or government based on their respective electoral outcomes (Wyatt 1999). This differentiation between (pre-election) alliances and (post-election) coalitions is fundamental and is retained in the rest of this article. As Chaudhury (1969, pp 296-7) puts it, 'to share or not to share power is a dilemma when the alternative to sharing power is perhaps to lose it'.

From about the 1980s further refinements of coalition theory have extended the debate to institutional determinants of coalition formations, beyond the size and ideological considerations of the 1960s and 1970s (Kadima 2006, p 5). This theoretical dimension argues that the formation, management and survival of alliances and coalitions are equally conditioned by prevailing formal and informal institutional arrangements that define power configurations - how asymmetric power relations are structured in specific political environments and spheres. This quest explains ways and forms by which institutional factors promote, discourage or constrain political alliances and coalitions, as reviewed in the next section.

\section{Institutional determinants of alliances and coalitions}

Institutions are understood here as generally agreed formal and informal rules, scripts or devices, which provide a template of incentives to guarantee a socially regulated, compliant and predictable human interaction and sequence of decisionmaking (Ostrom 1996, p 2).

The assertion here is that cognitive intuition, courtesy and moral appropriateness are necessary but not sufficient to constrain variability and flexibility of social behaviour. Formal institutions - official rules of procedure, statutes, agreements or contracts that are explicitly codified, relatively invariable, impersonal and externally enforced - are critical due to their inherent compelling incentives for compliance and constraining sanctions for deviance (North 1990, p 4; Lindberg 2010, p 153). Examples include constitutions, alliance or coalition 
agreements, electoral laws, regime type, party system and parliamentary system (Bickers \& Williams 2001, p 41).

Understanding the simultaneous influence of informal norms, practices and traditions provides an instrumental perspective and knowledge in accounting for ancillary structural factors and drivers of human interactions, especially in most African countries, which are noted to be operating on institutional-dualism, formal and informal. Informal norms are unwritten, tacit, interpersonal, reciprocal, normative codes, and habitualised routines generally accepted and self-enforced outside official systems (Helmke \& Levitsky 2004).

Informal institutions that are competitive and substitutive tend to undermine compliance with formal rules. The social affection theory, as elaborated by Richard Emerson (1962) and Peter Blau (1964) is a model of the 'economy of affection' that captures the essence of informal norms by explaining the existence of the asymmetric social relations and interdependence that are ubiquitous in underdeveloped economies, emerging or hybrid democracies and classless societies in South East Asia, Latin America, Eastern Europe and Africa, where reliance is on a 'hand-shake rather than a contract' (Hyden 2006, pp 72, 85; Scott 1972, p 91). Where they exist, individuals invest in lateral and reciprocal relationships for the attainment of desired aspirations which are deemed to be otherwise unattainable (Hyden 2006, pp 72, 85; Scott 1972, p 91).

With regard to institutional factors that affect coalition formation in Africa, there is ample evidence in the literature to suggest that some institutional contexts are more compatible with the formation of alliances and coalitions than others. For example, Mauritius is one of the few African countries to have met Samuel Huntington's 'two-turnover test' of democratic consolidation (Logan \& Cho 2009, pp 3-4) and that the multi-ethnic island's economic development and political stability are attributable to the institutional design adopted at independence that encourages coalition compromises and regime alternation (Bräutigam 1999, p 138).

Elsewhere in Africa alliances and coalitions are uncommon in presidential regimes with centralised executive power that coexists with and enhances patronage politics (Clark \& Gardinier 1997; Chabal \& Daloz 1999). Alliances and coalitions are unfamiliar in plurality electoral systems, unitary states where the party system is also fragmented, such as Malawi, Zambia, and Kenya. As the Malawi case shows, floor crossing seems, remarkably and routinely, to replace formal alliances and coalitions at the risk of heightened executive-legislative acrimony and state instability. Further, dominant-party systems such as those in Mozambique, Tanzania, South Africa, Namibia, Zimbabwe and Botswana also have no tradition of alliances and coalitions and there are limited prospects for regime alternation with parties that have won transition elections maintaining an obstinate grip on state control (Van de Walle 2003, p 301). 
It is evident that even at times of unprecedented post-election volatility and extended governance crises, as seen in Malawi from 2004-2009 and 2012, Zimbabwe from 2003-2008 and Kenya, 2007-2008, there is an emerging trend away from formal coalitions towards collusive, exploitative and elite-centred political settlement mechanisms such as 'governments of national unity' or the 'powersharing' arrangements seen in Zimbabwe and Kenya (Matlosa \& Shale 2013, p 19).

Owing to a combination of extremely limited mutual trust, non-exhaustively negotiated partnership terms and severe democratic deficits anchored in patronage and vague agreements, such power-sharing arrangements collapse for lack of long-term legitimacy and binding commitments to balance political cooperation with political competition. In sharp contrast, political coalitions manifest more in minority governments of parliamentary systems, federal governments and proportional representation electoral systems, which also have relatively stable and cohesive party systems such as those in Israel, Italy, Germany, Belgium and Mauritius.

\section{Floor crossing as a substitute for coalitions}

Floor crossing, or party switching, is defined and classified differently in different political contexts (Lembani 2013, pp 76-78). In this article floor crossing refers to the regulated or discretionary movement of a legislator from his or her electoral party to another. The extent to which this practice occurs and is therefore regulated also varies significantly according to the stage of democratic development and institutional conditions that regulate political behaviour, as seen in table 1 .

As is apparent from table 1 floor-crossing laws 'are more peculiar and prevalent in emerging democracies but rare in established democracies' (Lembani 2013, p 76). The reason is that emerging democracies are often beset by unstable party systems and ineffectively enforced party laws in addition to limited intraparty democracy and unclear ideological distinctions among parties (Goeke \& Hartmann 2011, pp 264-265).

In their analysis of floor crossing in Africa Goeke \& Hartmann (2011) state that in nearly all cases of floor crossing in Africa 'MPs move from the opposition to governing parties, mostly lured by incumbency incentives of patronage and clientelism' (Lembani 2013, p 76). Induced by private benefits such ministerial appointments, business tenders and increased popularity through more targeted constituency development projects from government, opposition MPs in Malawi cross the floor to support the government with regard to legislative Bills, constitutional amendments and the approval of public appointments (Patel 2008, p 27). 


\section{Table 1}

Nations with laws against parliamentary party defections

\begin{tabular}{|l|c|c|l|}
\hline $\begin{array}{l}\text { Type of democracy, } \\
2007\end{array}$ & $\begin{array}{c}\text { Number of } \\
\text { nations }\end{array}$ & $\begin{array}{c}\text { Number with } \\
\text { floor-crossing } \\
\text { laws }\end{array}$ & $\begin{array}{c}\text { Nations with floor-crossing } \\
\text { laws }\end{array}$ \\
\hline Older democracies & 36 & $4(14 \%)$ & $\begin{array}{l}\text { India, Israel, Portugal, } \\
\text { Trinidad \& Tobago }\end{array}$ \\
\hline Newer democracies & 54 & $13(24 \%)$ & $\begin{array}{l}\text { Belize, Bulgaria, Ghana, } \\
\text { Guyana, Hungary, Lesotho, } \\
\text { Mexico, Namibia, Romania, } \\
\text { Samoa, Senegal, Suriname, } \\
\text { Ukraine }\end{array}$ \\
\hline Semi-democracies & 58 & $19(33 \%)$ & $\begin{array}{l}\text { Armenia, Bangladesh, } \\
\text { Fiji, Gabon, Kenya, } \\
\text { Macedonia, Malawi, Uganda, } \\
\text { Mozambique, Nepal, Niger, } \\
\text { Nigeria, Papua New Guinea, } \\
\text { Seychelles, Tanzania, Sierra } \\
\text { Leone, Singapore, Sri Lanka, } \\
\text { Zambia }\end{array}$ \\
\hline Non-democratic & 4 & $4(9 \%)$ & $\begin{array}{l}\text { Congo (Democratic Republic), } \\
\text { Pakistan, Thailand, Zimbabwe }\end{array}$ \\
\hline TOTAL & $\mathbf{1 5 2}$ & $\mathbf{4 0}$ & \\
\hline
\end{tabular}

Source: Janda 2009, p 4, compiled by author

More than 25 by-elections held between 1994 and 1999 resulted from floor crossing (Patel 2008, p 27). More legislators crossed the floor between 1999 and 2004 during the then President Bakili Muluzi's third-term bid (see below). The largest number of defections, involving more than 65 legislators, took place after President Bingu wa Mutharika fell out with the United Democratic Front (UDF), the party that had elected him, in 2005 and formed his own party, the Democratic Progressive Party (DPP) (Patel 2008, p 27; Goeke \& Hartmann 2011, p 275; Resnick 2012, p 8). The epitome of the practice was the massive movement of more than half of all DPP MPs to support President Joyce Banda's People's Party (PP) after the death of Mutharika in April 2012 and the relegation of the DPP to the opposition. As elaborated below, these defections have served as a substitute for formal coalitions in Malawi.

The above synthesis has attempted to set the theoretical scope and broad political context within which to locate and examine institutional and structural factors which explain the processes, challenges and scenarios of political alliances and coalitions in general. The discussion in the next section focuses on institutional, 
political and structural factors in Malawi and how they have enhanced or impeded alliances and coalitions. Using both documentary analysis and empirical evidence, the rest of the discussion in this article interfaces institutions, actors and strategies with political alliances and coalitions in Malawi and the implications for democratic consolidation, state governability and national cohesion since the transition elections in 1994.

\section{POLITICAL CONTEXT AND PROFILE}

Malawi reverted to multiparty democracy in 1994 after 30 years of postindependence single-party rule under President Kamuzu Banda and the Malawi Congress Party (MCP). Until 1964, and before the country was officially declared a one-party state, three other parties were registered but were effectively delegalised in 1966 after their poor performance in the first multiparty elections in 1962.

The 1966 Constitution replaced the parliamentary system of government left by the British colonial regime with a presidential system, while retaining a firstpast-the-post (FPTP) or plurality system along with a constituency-based voting system for parliamentary representatives (Lembani 2011, pp 6-8). Multiparty politics was reintroduced in 1994 under a new and overly permissive law enacted in 1993. The retention of the FPTP system, however, provides the incentive for aspiring presidential candidates to anticipate securing the coveted executive presidency with marginally more votes than other contestants, even without an electoral alliance. This was particularly discernible when Mutharika became president with about $35 \%$ of the total vote in 2004 while the other votes were split among the four other presidential hopefuls.

Table 2

\section{Malawi's political features and social indicators}

\begin{tabular}{|l|l|}
\hline Electoral system & Plurality or First-Past-The Post \\
\hline Regime type & Executive presidential system \\
\hline Parliamentary system & Unicameral \\
\hline Party system & Fragmented \\
\hline Population & 14.9 -million \\
\hline Life expectancy & 54.8 years \\
\hline Urban population & $20 \%$ \\
\hline Real GDP Growth & $4.3 \%$ in $2012,9 \%$ in 2009 \\
\hline Human Development Index rank & 170 out of 187 \\
\hline
\end{tabular}


Although the 2008 national population census put the population at 13.09-million (NSO 2008, pp 3-11) (regionally distributed as $13.1 \%, 42.1 \%$ and $44.8 \%$ for the north, centre and south, respectively), while the 2012 HDI and BTI estimate the population at nearly 15 -million. When disaggregated across religious affiliations, the 2008 census report indicated that $83 \%$ were Christians and 13\% Muslims, while those subscribing to other religions and without religious affiliation comprised $2 \%$ each. Even though the role of religious leaders, especially the Catholic and Anglican bishops, has been very significant in Malawi's politics, religion itself has not been a politically divisive or decisive factor. Further, the literacy rate - defined as the ability to read and write in any language - was $64 \%$, though with only $16 \%$ of the total population having at least attained secondary education. Thus, the national population remains significantly semi-literate. About $80 \%$ is rural-based, poor and mostly engaged in subsistence agriculture (ICEIDA 2012, p 12). The country's economy is based on intermediate exports of tobacco, tea and groundnuts, limited extractive mining and processed cane sugar.

\section{Political institutions and party system}

Politically, Malawi is a unitary state with three regional administrative centres north, centre and south - with no legislative autonomy. The unicameral National Assembly consists of the country's 193 constituency seats, whose representatives are directly elected under the plurality system. The Senate (ss 68-72 of the 1995 Constitution) was abolished in 2001 by a unanimous vote of Parliament to consolidate executive power in the single-chamber Parliament in defiance of the dominant public view and unsuccessful petitioning for its retention (Patel 2008, p 5; EISA 2007, p 30; Cammack 2009, p163). Both the president and the legislators serve five-year terms, renewable every five years for the MPs and for a maximum of two terms for the president (Malawi Constitution 1999, ss 67, 83 pp 1-3).

The party system remains fragmented and weakly institutionalised. Organisationally, political parties are challenged by legacies of patronage and serious democratic deficits, especially over leadership succession and primary elections for legislative candidates. It has been contended that political patronage, clientelism and nepotism are preserved by and embedded in formal rules which centralise power 'in the hands of the President (vis-à-vis parliament, the judiciary, and parastatals, local and district government, ruling party machinery, and chiefs)' (Cammack 2011 p 2; 2009, p 155). In addition, since 1995 there have been recurrent incidents of floor crossing or party switching from the opposition to support minority governments. Political parties are transient, with muted, vague or non-existent ideologies and no deterministic effect on voters' choices (Lembani 2011, pp 12-13; Phiri 2000, p 68). All parties employ unstructured methods of 
mobilising their members, predominantly using public rallies. Party ownership remains personalised in the president, who is the main financier of party activities, while the identification and estimates of membership are imprecise and intuitively based on party colours (Khembo 2004, p 105). The legislative performance of all political parties across four general elections is reflected in Table 3.

Table 3

Performance of Malawi's Political Parties in Four General Elections

\begin{tabular}{|c|c|c|c|c|}
\hline Political Party & 1994 & 1999 & 2004 & 2009 \\
\hline United Democratic Front (UDF) & $85(48 \%)$ & $93(48 \%)$ & $49(25 \%)$ & $17(8.8 \%)$ \\
\hline Malawi Congress Party (MCP) & $56(31.6 \%)$ & $66(32.6 \%)$ & $58(30 \%)$ & $27(14 \%)$ \\
\hline Alliance for Democracy (AFORD) & $36(20 \%)$ & $29(15 \%)$ & $6(3 \%)$ & $1(0.5 \%)$ \\
\hline $\begin{array}{l}\text { Malawi Forum for Unity and } \\
\text { Development (MAFUNDE) }\end{array}$ & $\mathrm{N} / \mathrm{A}^{*}$ & $\mathrm{~N} / \mathrm{A}$ & $\mathrm{N} / \mathrm{A}$ & $1(0.5 \%)$ \\
\hline National Democratic Alliance (NDA) & $\mathrm{N} / \mathrm{A}$ & $\mathrm{N} / \mathrm{A}$ & $8(4.1 \%)$ & $\mathrm{N} / \mathrm{A}$ \\
\hline Republican Party (RP) & $\mathrm{N} / \mathrm{A}$ & $\mathrm{N} / \mathrm{A}$ & $15(7.8 \%)$ & 0 \\
\hline Peoples Progressive Movement (PPM) & $\mathrm{N} / \mathrm{A}$ & $\mathrm{N} / \mathrm{A}$ & $8(4.1 \%)$ & 0 \\
\hline Movement for Genuine Democracy & $\mathrm{N} / \mathrm{A}$ & $\mathrm{N} / \mathrm{A}$ & $3(1.6 \%)$ & $\mathrm{N} / \mathrm{A}$ \\
\hline People's Transformation Party (PETRA) & $\mathrm{N} / \mathrm{A}$ & $\mathrm{N} / \mathrm{A}$ & $1(0.5 \%)$ & 0 \\
\hline Democratic Progressive Party & $\mathrm{N} / \mathrm{A}$ & $\mathrm{N} / \mathrm{A}$ & $\mathrm{N} / \mathrm{A}$ & $114(59 \%)$ \\
\hline Independents & $\mathrm{N} / \mathrm{A}$ & $4(2 \%)$ & $39(20 \%)$ & $32(16.6 \%)$ \\
\hline Total Number of Parties & 8 & 11 & 15 & 6 \\
\hline Total number of Seats & 177 & 192 & 192 & 192 \\
\hline
\end{tabular}

Source: Compiled by the author from Malawi Electoral Commission results, various years ${ }^{*} \mathrm{~N} / \mathrm{A}=$ non-existent - either the party / group was not registered or was abolished

Table 3 shows that the number of parties changed from three (between 1994 and 2004) to eight (between 2004 and 2009) and to five after the 2009 elections. It also shows the significant increase in the number of independent MPs from four in 1999 to 39 in 2004 and 32 in 2009. This is attributed to flawed party primary elections, in which the candidates favoured by the parties were different from those preferred by the voters (Khembo 2004, p 11). Legislative turnover was high in the 1999, 2004 and 2009 elections, averaging 75\%. In the 2004 and 2009 elections there was a marked decline in support for the parties, particularly the UDF and the Alliance for Democracy (AFORD), who lost their seats, mainly to splinter parties and independent candidates (Mpesi 2011, p 27). 
The configuration of political parties in the legislature, especially after 2004, is indicative of party fragmentation and the status of the parties' organisational capacity to counter rising unpopularity (Kadima \& Lembani 2006). There were three reasons for President Mutharika and the DPP's victory in securing nearly $60 \%$ of the legislative seats and $66 \%$ of the presidential votes in 2009 evenly distributed across the country.

The first was a protest vote against the MCP and the UDF over their MPs' conduct when they were pressured to pass the national budget between 2005 and 2008 (Chinsinga 2009, p 148). ${ }^{2}$ During this period opposition party leaders stubbornly insisted on linking the passage of the budget prior to the dismissal of parliamentarians who, in supporting Mutharika's minority government, were deemed to have crossed the floor. Traditional leaders were marshalled along with civil society groups and university students to compel MPs to pass the budget two months into the new financial year. The opposition relented on its 'No Section 65, No Budget' slogan and reluctantly passed the budget only when it was apparent that the electorate was becoming increasingly enraged (Chinsinga 2009, p 132).

The second reason was that since Mutharika had come from a narrow and humble political background his only option was to advance policies that would generate the necessary political support. Thus, his agricultural inputs subsidy programme, launched in 2005/2006 on the back of good weather conditions, was widely credited by the general public as well as donors with having spurred increased productivity and food security (Mpesi \& Muriaas 2012, p 10). Increased food security was complemented by improved road infrastructure, sound macroeconomic policies and favourable donor inflows, which led to superior economic growth - the gross domestic product (GDP) growth rate averaged $8 \%$ between 2005 and 2009. These factors may have fundamentally contributed to the DPP's landslide victory (Chinsinga 2009, p 149).

The third reason was that out of the disorganisation and chaos that followed the Electoral Commission's eleventh-hour rejection of Muluzi's candidacy the UDF found itself stranded with no presidential candidate. Muluzi was rejected by the EC because he was constitutionally not eligible for a third presidential term, having served in that position for two successive terms between 1994 and 2004. Muluzi's subsequent signing of an electoral alliance agreement with the MCP less than 72 hours before the elections raised more curiosity and controversy than hope among both UDF and MCP followers. It ultimately restricted the choice of sceptical MCP/UDF voters of a presidential candidate

2 Based on the 2008 Afrobarometer study, which showed that $76 \%$ of the people believed that Parliament should prioritise the passing of the national budget over floor crossing, Chinsinga notes that the 2009 election results were a backlash against the opposition parties. 
since the two alliance partners were unable to develop sufficient mutual trust and campaign for their joint presidential candidate, the MCP's John Tembo. The desperate and illusory hopes of the two parties were premised on the hope that they would garner sufficient presidential votes from their parties' respective regional enclaves (Chinsinga 2009, p 148). Cumulatively, the above factors may have swayed popular support towards the DPP's massive election victory in 2009.

\section{Legislative configurations across four elections - the case for coalitions}

With the exception of the overwhelming victory of the DPP in 2009 all other elections had resulted in combined majority legislative seats for the opposition parties and a minority party for the president controlling the executive - a scenario referred to as divided government. Logically, this state of affairs justified the formation of formal coalition governments to ensure governance stability. Yet the Muluzi and Mutharika governments survived their tenures without any meaningful government coalitions and, after about 18 months in government and six months before the 2014 elections, the Joyce Banda administration seemed set to do the same.

The regional spread of legislative seats for all parties in the 1994/1999 elections is shown in Table 4. The results illustrate that the party of the state president-UDF had no decisive parliamentary majority despite the fact that the number of constituencies increased from 177 in 1994 to 193 in 1999. The table also shows that the election results for the three legislative parties between 1994 and 2004 were regionally based, with AFORD, the MCP and the UDF winning more than two-thirds of the votes in the north, centre and south (Mpesi 2011, p 27) respectively.

On this basis government coalitions were justified to ensure state governability, national cohesion and an enhanced party system. Yet, as the following sections show, each administration resorted to patronage politics and opportunistic Cabinet appointments of MPs who pledged support to the Muluzi and Mutharika administrations (Chinsinga 2009, p 143). The legislative dominance of the MCP and the UDF was remarkably contracted in the 2009 elections, mainly by what seemed to be a decisive vote against the opposition parties' 'stubbornness' in the inter-election period, giving the DPP a windfall of 'sympathy' votes. The MCP's legislative seats diminished from 59 to 26, while its 2009 alliance partner, the UDF, won 17 seats, down from 49 in 2004. As for AFORD, they were reduced to one seat from the six they had won in 2004. By contrast, the DPP moved from six seats in 2005 - all won through by-elections, to a comfortable majority of 114 seats spread across all regions. 


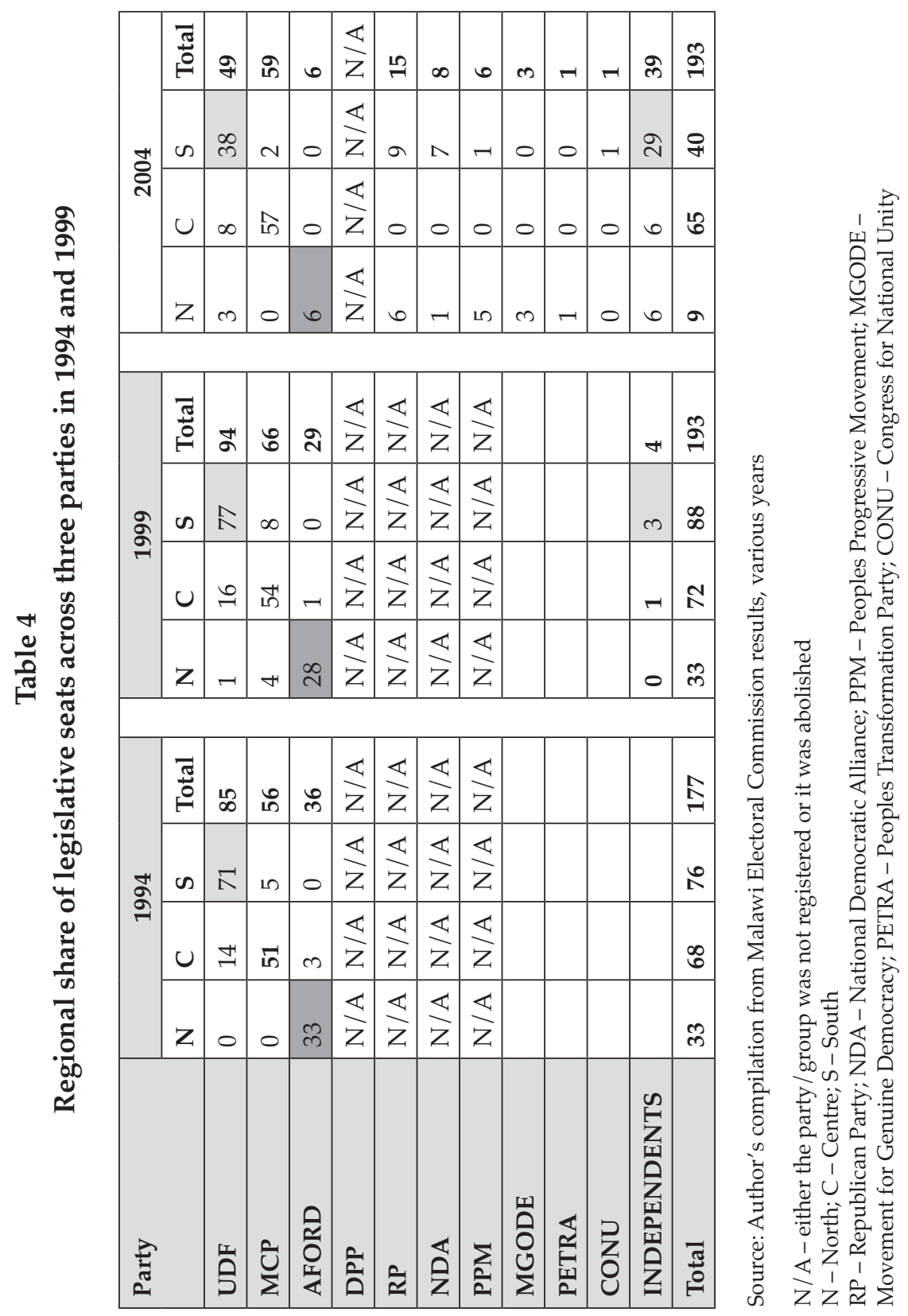




\section{CAUSES OF PARTY ALLIANCES AND COALITIONS}

Apart from the 1999 and 2004 elections, in which both opposition parties and the party in government at the time (the UDF) formed separate electoral alliances, as discussed above, the phenomenon of electoral alliances and coalitions has not gained popular appeal in Malawi. Thus it is critical to start answering the question whether opportune junctures existed in Malawi for alliances and coalitions. The answer is 'Yes!' and more than once. Different opportunities emerged for potential alliance and coalition formations. However, partners opted to align with each other or stay apart for various reasons including:

- Revenge by opposition majorities against minority governments whose electoral victory was contested;

- A perceived common political 'enemy' of the allied parties based on personal victimisation, trumped up treason charges and / or 'political persecution';

- Sheer malevolence or hunger for power - 'if not us in government, then no one else'; and

- External influence of concerned civic and religious leaders pressuring for a change of government in the face of deteriorating socio-economic and political conditions.

The first electoral alliance, mooted prior to 1994, was led by the UDF with five smaller political parties (Kadima \& Lembani 2006, p 122). None of the five small parties secured a parliamentary seat and disappeared into oblivion as their leaders were offered appointments in parastatals or diplomatic missions. Since the alliance disbanded soon after the elections this article does not discuss it. This analysis limits itself to: the 1994-1995 MCP / AFORD coalition and the 1994-1995 UDF / AFORD coalitions; the 1997-1999 AFORD/MCP-led Mgwirizano alliance; the 2003-2004 Mgwirizano alliance and the 2004-2005 UDF/DPP coalitions; the 2009 MCP / UDF alliance and the mid-2012 PP-led government of national unity with the UDF, MCP and AFORD, formed after the death of President Mutharika in April 2012.

The MCP-AFORD coalition (1994-1995) and the UDF-AFORD coalition (1995-1996)

The 1994 presidential and parliamentary election results showed two major trends. First, a distinct split of votes on regional lines. Second, the governing party, the $\mathrm{UDF}$, did not win a clear legislative majority. Consequently, AFORD and the MCP 
formed an informal coalition or 'collusion' to effectively impede government business in Parliament. To resolve the state of un-governability posed by recurrent parliamentary boycotts and sabotage a constitutional provision (s 80(5)) was created for the position of a second vice-president to insulate government coalitions (Cammack 2009, p 163).

A government coalition was established in 1995 between the UDF and AFORD, in which AFORD's leader, Chakufwa Chihana, was made second vicepresident of the Republic and six MPs received ministerial positions (Kadima \& Lembani 2006, p 123). Although this 'minimum winning coalition' was short lived - Chihana resigned in 2006 amid allegations of widespread corruption in government - the coalition was hailed as the most objectively conceived to date. It facilitated speedy legislative decision-making, ended recurrent opposition boycotts and therefore stabilised state governance and enhanced national cohesion, at least in the short term (interviews with Dan Msowoya, Boniface Chibwana and Ian Nankhuni).

Four additional outcomes were apparent. First, with the six AFORD MPs still in government, the coalition left AFORD's internal cohesion fractured and weakened since the six 'rebel' MPs would support the government agenda, which AFORD would naturally oppose. Second, it was revealing that ideology played no part in opposition coalitions or the government's coalition with any of the partners. For AFORD, the MCP, whose one-party regime it had described in its pre-1994 campaign as the party of 'darkness and blood', was now to become an opposition legislative ally before and after its alignment with UDF. The 'making, unmaking and remaking' of these paradoxical political alignments partly explains the insignificant influence of ideological considerations in electoral alliance and post-election coalitions. Third, they are driven by convenience not substance among rational actors aimed at maximising private and short-term incumbency gains for the leaders and their lieutenants.

The 1995 government coalition collapsed because pressure was building up against Chihana because of unmet promises of further ministerial appointments (interview with Dan Msowoya). This is linked to the fourth factor-patrimonialism and patronage politics, which are intricately embedded in the political culture of democratic Malawi to the extent that they significantly determine political associations. President Muluzi used appointment inducements to lure AFORD MPs who had pledged their loyalty to Chihana. Some informants observed that what influenced the six MPs to accept Cabinet positions was the intrinsic personal financial security, for which they exchanged cooperation and support for Muluzi and the UDF (interviews with Humphrey Mvula and Dan Msowoya). Several other $\mathrm{MCP}$ and AFORD MPs declared themselves independent when in fact they had been lured by various favours from the UDF to improve its position in Parliament 
(Kadzamira 2000, p 59). This supports the view that neo-patrimonialism is discernible where 'power and legitimacy are built on politics of personalities, centred on big men and their networks rather than parties with clear ideologies and programmes ... [and] fluid political alliances [are] primarily based on the quest for power rather than issues or principles or norms ...' (Chinsinga 2009, p 121).

\section{THE AFORD / MCP-LED MGWIRIZANO ALLIANCE (1997-1999)}

The interchangeable use of the terms coalition and alliance in Malawi's contemporary politics was most prominent in 1999 and 2004 when the pre-election alliance codenamed Mgwirizano (literally meaning unity) was referred to as a coalition. Based on the conceptual clarifications above, the rest of this article accordingly refers to it as an alliance. Initially formed between the MCPChakuamba faction and AFORD in the hope that their combined forces would produce a landslide victory in the 1999 general elections and unseat the UDF, the motivation was a shared grave disenchantment with the Muluzi administration (interview with Ian Nankhuni).

Chihana and MPC president Gwanda Chakuamba dominated Malawi's experiments with alliances and coalitions until 2004. The initial pairing in 1997 prepared the ground for the two parties' electoral alliance in 1999. Although the alliance was a rational office-seeking option it effectively accentuated the preexistent leadership rift in the MCP which resulted in divided loyalties between the factions ranged behind John Tembo and Gwanda Chakuamba, especially when the latter nominated Chihana as his running mate in 1999 (Khembo 2004).

In terms of the way the 1999 alliance partners were identified it was clear that civic and religious leaders, especially Christian church leaders including the Catholics, Anglicans and Evangelicals, conceived the idea and decided who would comprise the alliance partner in order to unseat Muluzi in the midst of deteriorating governance and grave economic policy malaise (Kadima \& Lembani 2006, p 123). As expected, the religious groups were reproved by the Muluzi administration. Although the UDF retained power in 1999, the results reflected in Table 5 (a 7\% margin between Muluzi and his immediate rival, Chakuamba) show that a substantial number of voters wanted a change of government in favour of the MCP-AFORD coalition.

It is also evident that the axis of the MCP's factionalism, especially after Chakuamba chose Chihana as his running mate, was inimical to its internal cohesion (Khembo 2004). Table 6 shows that while presidential contests are increasingly competitive, splits, alliances and coalitions are affecting political parties negatively and further weakening the fragile party system. 
Table 5

Presidential Election Results

\begin{tabular}{|c|c|c|c|c|c|}
\hline \multicolumn{2}{|c|}{1994} & \multicolumn{2}{|c|}{1999} & \multicolumn{2}{|c|}{2004} \\
\hline Candidate & $\begin{array}{l}\text { Votes } \\
(\%)\end{array}$ & Candidate & $\begin{array}{c}\text { Votes } \\
(\%)\end{array}$ & Candidate & $\begin{array}{c}\text { Votes } \\
(\%)\end{array}$ \\
\hline $\begin{array}{l}\text { Bakili } \\
\text { Muluzi } \\
\text { (UDF) }\end{array}$ & $\begin{array}{r}1404754 \\
(47.16)\end{array}$ & $\begin{array}{l}\text { Bakili } \\
\text { Muluzi } \\
\text { (UDF) }\end{array}$ & $\begin{array}{r}2442685 \\
(51.37)\end{array}$ & $\begin{array}{l}\text { Bingu Wa } \\
\text { Mutharika }\end{array}$ & $\begin{array}{r}1119738 \\
(35.8)\end{array}$ \\
\hline $\begin{array}{l}\text { Kamuzu } \\
\text { Banda } \\
\text { (MCP) }\end{array}$ & $\begin{array}{r}996353 \\
(33.45)\end{array}$ & $\begin{array}{l}\text { Gwanda } \\
\text { Chakuamba } \\
\text { (Mgwirizano } \\
\text { Alliance) }\end{array}$ & $\begin{array}{r}2106790 \\
(44.3)\end{array}$ & $\begin{array}{l}\text { John Tembo } \\
\text { (MCP) }\end{array}$ & 833027 \\
\hline $\begin{array}{l}\text { Chakufwa } \\
\text { Chihana } \\
\text { (AFORD) }\end{array}$ & $\begin{array}{r}562862 \\
(18.90)\end{array}$ & & & $\begin{array}{l}\text { Gwanda } \\
\text { Chakuamba } \\
\text { (Mgwirizano } \\
\text { Alliance) }\end{array}$ & 802386 \\
\hline & & & & $\begin{array}{l}\text { Brown } \\
\text { Mpinganjira } \\
\text { (NDA) }\end{array}$ & 272172 \\
\hline & & & & $\begin{array}{l}\text { Justin } \\
\text { Malewezi } \\
\text { (Independent) }\end{array}$ & 78892 \\
\hline
\end{tabular}

Source: Compiled by the author from Malawi Electoral Commission results, various years

The regional share of votes and seats for each party across all election years makes it evident that 'ethnicity and regionalism remain a source of political cleavage in Malawi' (Khembo 2004, p 113).

Soon after Muluzi was declared the winner of the closely contested 1999 election Chakuamba swiftly abandoned the Mgwirizano electoral alliance group, announcing his alignment with Muluzi, leaving the other alliance partners, who were challenging the allegedly 'stolen' election, dejected and disillusioned. Chihana's 'weird flexibility' with alliances and coalitions was visible as he yielded to the call to join Muluzi's open-term agenda in 2002, which sought to remove the constitutional limitation of two five-year presidential terms.

This campaign, which began soon after the 1999 elections, gained momentum, proved politically divisive and significantly strained national cohesion. Although 
the June 2002 AFORD national convention resolved neither to join the UDF government nor to support its open-term agenda, Chihana unilaterally defied the decision, was restored as second vice-president of the Republic (interview with Dan Msowoya) and, along with some AFORD MPs, voted for the proposed removal of the limitation, a decision that ripped AFORD apart.

\section{Post-1999-2004: The UDF/MCP/AFORD coalitions and the Mgwirizano alliances}

The move to extend Muluzi's tenure gathered momentum when Chihana and Tembo supported it after 2001. Tembo, then Leader of Opposition, and his MCP MPs, along with nearly all the AFORD MPs, acting as informal pro-government legislative coalition partners, voted in support of the amendment in July 2002 (Kadima \& Lembani 2006, p 125). Other progressive MCP MPs, led by Ishmael Chafukira, called for Tembo's resignation from politics, believing that his support for an extended term signalled that he was not ready to take the MCP into government. At the same time a 'hybrid' alliance comprising civic leaders, political pressure groups like the NDA, non-governmental organisations, activists, the Forum for the Defence of the Constitution (FDC), academics and constitutionminded individual citizens opposed to the removal of presidential term limits emerged (Kadima \& Lembani 2006, p 125).

The resurgence of bad governance between 2001 and 2004, coupled with growing concerns about corruption in government, declining social indicators, deteriorating road infrastructure, nepotism and politicisation of the police service prompted civic and religious leaders to identify and approach pre-2004 opposition alliance partners - the MCP, RP, PPM, MAFUNDE, the National Unity Party (NUP), the Malawi Democratic Party (MDP), PETRA and MGODE to form an electoral alliance.

Partly inspired by the success of the National Rainbow Coalition (NARC) in Kenya, which ended the 39-year rule of the Kenya African National Union (KANU), the motivation was to replace Muluzi and prevent him from controlling state affairs through Mutharika beyond 2004. Common among these opposition parties was the one political enemy, the UDF regime and Muluzi's hegemony. The UDF-led electoral alliance, on the other hand, aimed to retain power and maximise its legislative seats through Mutharika, their second-best option in view of the failure of the bid to extend Muluzi's term of office.

The MCP refused to join the 2004 Mgwirizano opposition alliance, saying that as the biggest opposition party it would only join if its leader, John Tembo, was made presidential candidate for the alliance. Mpinganjira's NDA, a faction that broke away from the UDF over Muluzi's undemocratic succession, ambitiously 
claimed to be popular enough to face the polls alone. The party claimed that it controlled a large share of the populous southern region. MGODE, a fragment of AFORD and the Republican Party (RP), from the MCP, had broken away from their parties because of leadership disputes. It was obvious that Tembo and Chakuamba's irreconcilable personality clashes, rooted in the past, were decisive reasons why the two would never be able to work together and the combination of malevolence, bad blood, opportunism and egotistical presidential ambitions came at a huge cost for the opposition.

Table 5 shows that had Tembo and Chakuamba agreed to work together under the Mgwirizano Alliance they would have won nearly twice the number of votes that went to Muluzi's hand picked successor, Mutharika. Mutharika's win in 2004 was, therefore, a classic consequence of the attitude 'if not us in government, then no one else' which constitutes part of Malawi's political culture of envy and he assumed the presidency with a mere $35.8 \%$ of the total votes cast. The majority of the voters had rejected the UDF and its candidate, yet the plurality electoral system gave him the presidency and, along with it, a legitimacy crisis within the UDF (Dulani 2004, p 14).

Sensing this disaffection, reflected in the more than $64 \%$ of the vote that had gone to opposition candidates, Mutharika opted to resolve the looming legitimacy crisis by suggesting a government of 'national unity', not a formal coalition with all the opposition parties in the legislature. The 2004 post-election coalition reconfiguration, engineered by Muluzi, was unusually swift but consistent with what Diana Cammack (2009, p 153) refers to as being an 'opportunistic and duplicitous nature [with the] chameleon-like character of multiparty era politicians, who, with ease, castigate opponents one day and welcome them with open arms the next day'. The RP and the MGODE, motivated by access to state resources, joined the UDF-led coalition government. Patronage politics took its toll with ever-expanding Cabinet appointments, mainly from among opposition legislators, to smooth the progress of government business in Parliament (Chinsinga 2009, p 143).

Events accelerated and Malawi next had to cope with Mutharika's defection a few months after the election from the UDF, which had nominated him, and his establishment of his own party, the Democratic Progressive Party. The resentments and power struggle that followed the UDF's relegation to the opposition and the perils that emanated from Mutharika's resignation have been cogently documented by many scholars (see, eg, Ott \& Kanyagolo 2009). Table 6 shows that the decline in the regional share of votes for the MCP, UDF and AFORD is attributed to the increase in breakaway parties and independent candidates in regions which share a common ethnic identity with the established parties (Khembo 2004, p 113). 
Table 6

2009 Presidential Election Results

\begin{tabular}{|c|c|c|c|c|}
\hline \multirow[t]{2}{*}{ Candidate(s) } & \multicolumn{3}{|c|}{ Regional share of the total valid votes } & \multirow{2}{*}{$\begin{array}{c}\text { Total valid } \\
\text { votes } \\
(\%)\end{array}$} \\
\hline & $\begin{array}{l}\text { North } \\
(\%)\end{array}$ & $\begin{array}{c}\text { Centre } \\
(\%)\end{array}$ & $\begin{array}{l}\text { South } \\
(\%)\end{array}$ & \\
\hline $\begin{array}{l}\text { Bingu wa Mutharika } \\
\text { (DPP) }\end{array}$ & $650791(95)$ & $937163(52.6)$ & $1358149(68)$ & $\begin{array}{l}2946103 \\
\quad(66)\end{array}$ \\
\hline $\begin{array}{l}\text { John Tembo (MCP / } \\
\text { UDF Alliance) }\end{array}$ & $\begin{array}{c}20829 \\
(3)\end{array}$ & $\begin{array}{c}780522 \\
(44)\end{array}$ & $\begin{array}{c}568693 \\
(28)\end{array}$ & $\begin{array}{c}1370044 \\
(31)\end{array}$ \\
\hline $\begin{array}{l}\text { Kamuzu Chibambo } \\
\text { (PETRA) }\end{array}$ & $\begin{array}{c}2496 \\
(0.3)\end{array}$ & $\begin{array}{c}14912 \\
(0.8)\end{array}$ & $\begin{array}{c}17759 \\
(0.9)\end{array}$ & $\begin{array}{c}35167 \\
(0.7)\end{array}$ \\
\hline $\begin{array}{l}\text { Loveness Gondwe } \\
\text { (NARC) }\end{array}$ & $\begin{array}{l}3974 \\
(0.5)\end{array}$ & $\begin{array}{c}13697 \\
(0.8)\end{array}$ & $\begin{array}{c}14489 \\
(0.7)\end{array}$ & $\begin{array}{c}32160 \\
(0.7)\end{array}$ \\
\hline Stanley Masauli (RP) & $\begin{array}{l}2163 \\
(0.3)\end{array}$ & $\begin{array}{c}15620 \\
(0.9)\end{array}$ & $\begin{array}{c}16104 \\
(0.8)\end{array}$ & $\begin{array}{c}33887 \\
(0.7)\end{array}$ \\
\hline James Nyondo & $\begin{array}{l}1999 \\
(0.3)\end{array}$ & $\begin{array}{c}12803 \\
(0.7)\end{array}$ & $\begin{array}{c}12526 \\
(0.6)\end{array}$ & $\begin{array}{c}27328 \\
(0.6)\end{array}$ \\
\hline $\begin{array}{l}\text { Dindi Gowa Nyasulu } \\
\text { (AFORD) }\end{array}$ & $\begin{array}{l}3936 \\
(0.6)\end{array}$ & $\begin{array}{l}6444 \\
(0.4)\end{array}$ & $\begin{array}{r}9771 \\
(0.5)\end{array}$ & $\begin{array}{c}20151 \\
(0.4)\end{array}$ \\
\hline Total & 686188 & 1781161 & 1997491 & 4464840 \\
\hline
\end{tabular}

Source: Compiled by the author from Malawi Electoral Commission results, various years

\section{The 2009 UDF/MCP alliance}

By 2009 the main opposition parties in Parliament, the UDF and the MCP, seemed to be conspiring against Mutharika's administration. As collaborators they were approaching the elections with one goal - to remove Mutharika by the ballot, having desperately but unsuccessfully attempted to remove him through legislative impeachment (Chinsinga 2009, pp 128-129). However, their anti-government legislative machinations shifted public sympathy towards the widely perceived political 'victim', Mutharika, and increasingly isolated the two opposition parties from popular good will as the 2009 elections drew closer.

After the MEC rejected Muluzi as a candidate the UDF found that it had no presidential candidate. This was not surprising as Muluzi may have foreseen this scenario but deliberately failed to provide the party with an alternative candidate who would consolidate his power once in government and frustrate the ascendancy of Muluzi's son, Atupele, who was being earmarked for the 
presidency by Muluzi himself (interview, Humphrey Mvula). Considering Tembo a better enemy than Mutharika, Muluzi and Tembo agreed that Tembo would be the torch bearer for the MCP/UDF electoral alliance, with the UDF's Brown Mpinganjira as his running mate.

Like the earlier electoral alliances this one was hurriedly put together, its contents shrouded in secrecy and negotiated by trusted elites of Tembo and Muluzi (Chinsinga 2009, p 148). Paradoxically, the arrangement saw the two parties conducting a few joint rallies and whistle stops in Lumbadzi, Mponela, Dowa and Kasungu, all MCP strongholds (interviews with Boniface Chibwana, Humphrey Mvula and Ian Nankhuni). The message at the rallies was consistent with the parties' common agenda - a desperate electoral alliance resolved to remove Mutharika at all costs. Hitherto, their informal legislative cooperation had been the result of shared bitterness at finding themselves in opposition after the allegedly stolen 2004 election. Nonetheless, the alliance did not create mutual trust between these hitherto bitter political rivals.

It seemed that there was neither the time nor the intention to resolve unsettled questions between the two alliance partners, including who was to field which candidate and where. Intriguingly, the alliance agreement was signed only after the campaign tours and a mere 72 hours before the elections - a factor certain to precipitate an electoral showdown. Accordingly, both parties found themselves with a reduced number of parliamentary seats - two-thirds fewer for the UDF and a decisive 50\% loss for the MCP. Like all other previous alliances and coalitions this was another elite-centred 'collusion' with no consultation with party members and no substantive shared national agenda. Strikingly, even patronage politics and campaign handouts were insufficient to reverse the electoral fate of the two parties and deliver the presidential vote needed for the MCP/UDF alliance to torpedo Mutharika.

\section{The mid-2012 PP-led coalition government}

On 5 April 2012 President Mutharika died of cardiac arrest, barely two years into his second and final term in office. According to the constitutional order, the then vice-president, Joyce Banda, ascended to the presidency with her People's Party as a minority party in Parliament, while Mutharika's DPP, despite its majority in the legislature, was relegated to the opposition, thereby creating a mid-term regime alternation.

Taking a cue from her mentor, Mutharika, Banda had founded the PP along with legislators such as Anita Kalinde and former DPP second vice-president Khumbo Kachale, who, like Banda, had been expelled from the DPP because of allegations of involvement in setting up parallel political structures across the 
country, purportedly to prevent Peter Mutharika from inheriting the presidency from his older brother in 2014. The position of vice-president had been reduced to a symbol, affording Banda more time in 2011 to establish nationwide PP structures. She was overtly and covertly supported and encouraged by those within and outside of the DPP who were similarly opposed to the planned 'family succession' to the presidency. In mid-2011 the PP was officially registered under High Court orders after the DPP had covertly sabotaged its official registration by the Registrar of Political Parties, who rejected it. The tensions and acrimony between the two parties heightened as Mutharika made fruitless efforts to remove Banda from her vice-presidential post.

The report of a Commission of Inquiry into Mutharikas's death and the alleged attempt by the DPP to prevent Joyce Banda from assuming the presidency was submitted to President Banda in March 2013 (Nyasatimes online). As a result, Peter Mutharika, along with the chief secretary to the president and six former DPP ministers, dubbed the 'Midnight Six', were arrested and charged with attempted treason and intent to conceal the death of Mutharika, who, they had said at a press conference held close to midnight after Mutharika's death, was still alive but in a critical condition.

Not surprisingly, more than 40 DPP MPs defected to the PP (malawivoice online). Fifteen members of the 32-member Cabinet that Joyce Banda announced on 26 April 2013 were DPP MPs. The rest were mainly members from the MCP, AFORD and the UDF, including the UDF's 2014 presidential candidate, Atupele Muluzi. Only 13 were in Cabinet for the first time, an indication that not much would change (Dulani 28 April 2012). The ensuing political discontent from the UDF, DPP and MCP and some quarters within AFORD suggested that there was no openly negotiated intra-party agreement for a government of national unity. Instead there was collusion to support the PP government in exchange for Cabinet appointments and their attendant benefits. The few seats that had been taken by the UDF and MCP in 2009 were further decimated as their occupants switched to the PP (maravipost.com) in a move reminiscent of Muthurika's jilting of the UDF and formation of the DPP.

Not long after Joyce Banda appointed her first Cabinet the excluded political parties petitioned the Speaker to dismiss from Parliament all MPs who had switched their allegiance and support to the PP government. For their part, the 'floor crossers' obtained court injunctions restraining the Speaker's actions (malawivoice online 22 June 2012). Ironically, Mutharika himself had survived between 2004 and 2009 primarily because MPs were induced to cross the floor to join the DPP-led government and Muluzi exploited similar collusions with AFORD and MCP defectors between 1995 and 2004. Despite the existing anti-floor-crossing laws and the multiple violations of those laws in almost two decades of Malawi's 
democracy, only two legislators have lost their seats as a result of crossing the floor (Malawi Voice 19 February 2013).

\section{THE INSTITUTIONAL FRAMEWORK FOR PARTY ALLIANCES AND COALITIONS}

As indicated above the only piece of legislation that comes close to anticipating and catering for formal coalitions is the constitutional provision that creates the office of the second vice-president. Section 80(5) states:

Where the President considers it desirable in the national interest so to do, he or she may appoint a person to the office of Second VicePresident and may do so upon taking his or her oath of office or at any time thereafter or upon a vacancy in the office of Second VicePresident; and, where no person has been appointed to the office of Second Vice President then ... Provided that where the President was elected on the sponsorship of a political party, then he or she shall not appoint a Second Vice-President from that political party [Author's emphasis].

The emphasised portion suggests that the second vice-president must belong to a different party from that of the president. Apart from this provision, neither the electoral law nor any other legislation makes direct or implied statutory provision for political coalitions. In fact, the Malawi Electoral Commission (MEC) determined in 1999 that where the presidential candidate and his or her running mate come from separate political parties (as in electoral alliance partnerships) only the symbols and emblems of the presidential candidate's party will be printed on the ballot papers and any other MEC election materials except for those of the running mate's party.

As stated above, Malawi's presidential system, with its inherent expansive appointment powers, does not offer any effective incentives for the formation of political coalitions. Once the president is elected, even with a minority of votes, his or her survival and tenure does not depend on the sustained trust and confidence of the legislature. Further, while parliamentary rules of procedure do not officially provide for and acknowledge the existence of legislative coalitions, they do not explicitly inhibit them. The creation of the office of the leader of the opposition in Malawi's National Assembly denotes an explicit understanding that, hierarchically, all opposition parties in Parliament are both formally and informally headed by the leader of the opposition. This hierarchy is observed, for example, in the fact that the leader of opposition is the first to respond to the presidential address to Parliament on the State of Nation at each official opening 
of a parliamentary session. Similarly, parliamentary procedures and practice require that the leader of opposition is the first to respond to the national budget estimates presented by the minister of finance.

\section{Consequences for party coalitions and alliances}

The brief UDF / AFORD government coalition in 1995 / 1996 minimised opposition confrontations and legislative-executive tensions and expedited decision-making about government's policy proposals. In essence, the coalition was both the cause and the result of the constitutional amendment providing for the appointment of a second vice-president from a party other than that of the president when the president's party has a minority of seats. Although it does not specifically make this provision compulsory, the section formalises political coalitions that may potentially resolve legitimacy crises without necessarily weakening party discipline and violating the anti-floor-crossing legislation.

Section 80(5), if used to de-escalate ethnic tensions and ease state governability, could also enhance national cohesion. For example, after Chihana was appointed second vice-president in 1996, President Muluzi was freely able to hold public meetings in the AFORD stronghold of the north and indicate that the north, the centre (from which first Vice-President Malewezi came) and the south (Muluzi's homeground), were jointly running government affairs.

However, nearly all subsequent alliances and coalitions either deterred or undermined democratic consolidation, further fragmented the party system and created an increasing public aversion to alliances and coalitions. For example, most undemocratic constitutional amendments were introduced and swiftly passed during periods of pro-government legislative coalitions, with absolute disregard for resolute objections from NGOs, media, civic groups and the general public.

Among the controversial amendments were:

- The removal of the recall provision (s 64) from the Constitution in 1995 to ensure that MPs are not recalled by their constituency until the following election;

- The abolition of the Senate provision (s 68) in 2001 to ensure that the presidential open terms Bill would not be blocked by the second chamber;

- The amendment to the floor-crossing clause (s 65) in 2001 to ensnare MPs who opposed Muluzi's bid for limitless presidential tenure; and

- The 2001 amendment to section 50, in which the quorum required for the legislature to pass constitutional amendments was reduced from two-thirds to $50+1 \%$. 
Thus legislative majorities obtained through formal or informal agreements proved detrimental to democratic consolidation. In times when the country was governed by a minority party it is evident that alliances and coalitions enhanced the size and cohesion of legislative opposition parties to the extent that if these majorities supported government business that was in the national interest. On the other hand, whenever the majorities worked to advance personal and partisan interests and unconstructively blocked government business in Parliament, including the appointment of senior public officers, diplomats and approval of the national budget, such behaviour collided with public opinion, with costly electoral consequences. Thus, intra party discipline and cohesion was threatened by subsequent factions and splits emanating from public pressure on some MPs to extricate themselves from such extreme and narrow partisan positions. Under such circumstances, the already fragmented party system weakened further, making opposition parties scarcely viable alternative governments in waiting.

\section{Prospects for alliances and coalitions in Malawi}

The prospects for electoral alliances and coalitions in Malawi remain bleak. For slightly more than a year Nyasatimes ran an online opinion survey on the question, 'Should Malawi opposition parties form a Grand Alliance in 2014?' Arguably, online surveys have inherent multiple methodological and sample representation challenges which include being exclusive to the participation of the minority literate with access to the internet, while the opinions of majority voters are hardly represented. It is both striking and illustrative, however, to note that the survey results show that just under two-thirds $(64 \%)$ of the respondents oppose an opposition electoral alliance.

The survey began before the change of government in April 2012 and before any of the major political parties (MCP, UDF, DPP and PP) had held their conventions. Yet this general perception was not reversed or altered by the political events that took place in the year during which it ran. The signal was clear: there was no significant political support for an opposition alliance in 2014.

Table 7

Should Malawi Opposition Parties Form a Grand Alliance in 2014?

\begin{tabular}{|l|c|c|}
\hline \multicolumn{1}{|c|}{ Responses } & Percentage vote (\%) & Absolute votes \\
\hline No & 64 & 2253 \\
\hline Yes & 30 & 1061 \\
\hline Not sure & 6 & 219 \\
\hline Total & $\mathbf{1 0 0}$ & $\mathbf{3 5 3 3}$ \\
\hline
\end{tabular}

Source: Nyasatimes 
The view reflected in Table 7 is shared by some of those interviewed for this study. Asked about their hopes for alliance partnerships before the 2014 elections one respondent opined: 'Trends are not explicit, the population is indifferent, they have to be incited by church leaders or NGOs early enough ... they may likely respond favourably' (interview with Dan Msowoya). Other interviewees observed that they were not hopeful about the prospects for electoral alliances, given the discouraging history and effects of previous electoral and coalition pacts. Notwithstanding these opinions, and given that politicians in Malawi do not seem to learn from their or others' past mistakes, it is probably that political and electoral entrepreneurs will soon come to centre stage. Predictably, some small factional parties will dissolve and merge with bigger parties for a free ride over campaign expenses. Indeed, the political culture of opportunism and neopatrimonialism may be reactive and manifest again to influence the formation of the most improbable, elite-centred 'collusions', with no ideological basis or common ideals.

\section{TENTATIVE CONCLUSIONS: THE EFFECTS OF PARTY ALLIANCES AND COALITIONS}

Unlike most of Africa's emerging democracies where successive elections have often resulted in a majority vote for the president and the creation of a dominant governing party, Malawi offers unique insights. The results of the first three elections (1994, 1999 and 2004) resulted in the party in government having a minority of seats in the legislature. This provided a favourable and legitimate basis for formal coalition formations backed by section 80(5). Strikingly, these opportunities were under exploited or conveniently ignored in favour of systematically induced floor crossing. Thus, with the exception of the UDF/ AFORD coalition (1995/1996), all minority governments have survived their tenure through the support of opposition MPs who have defected to and supported the government, thereby negating the essence of formal coalitions.

Pessimism about and indifference to formal alliances and coalitions are perpetuated by an exploitative culture of informality, deference to hierarchy, political opportunism, neo-patrimonial reciprocities and a legal vacuum to encourage and regulate political coalitions by increasing the costs. Since 1994 the shifting and transient political alliances and coalitions have mainly been influenced by the flexibility and personal quest for power of Gwanda Chakuamba and Chakufwa Chihana. Experiments with electoral alliances were not based on ideological considerations but on narrowly defined short-term opportunism compounded by scarcely defined, extensively negotiated and mutually binding partnership agreements between and among political parties. Such transparently 
negotiated and electorate-centred alliance and coalition agreements anticipated and resolved the implications for electoral competition and support for mutual candidates and averted party fragmentation. They also set realistic targets and proximate attainable gains from such partnerships to inform the development of joint and winning electoral campaign strategies.

By contrast, the alliance and coalition experiments in the last four general elections yielded unintended and costly negative results for the partner parties, especially the smaller ones, thereby accentuating frustration and delusion. While smaller parties secured no seats in Parliament and eventually disappeared into oblivion, the regional political parties suffered remarkably, with diminishing legislative seats and severely compromised party cohesion.

From an institutional perspective, presidential regimes offer no incentives for mutual dependence and cooperation in executive-legislative relations. By design the president and the legislature are given mutually exclusive electoral mandates and tenures by the voters. This encourages executive arrogance, tyranny and unilateralism, which engender systemic paralysis until the expiry of the full term of office, without the option of dissolving the government and holding fresh elections, as is the case in parliamentary regimes. Mutharika's first term is a classic case in point.

In addition, the presidential system also concentrates extensive appointment and other constitutional or statutory powers in the president. This reinforces neo-patrimonialism, personalised power and patronage politics. Further, the winner-takes-all electoral law permits the creation and survival of minority governments, executive unilateralism and intolerance. This law neither anticipates nor sufficiently tackles the legitimacy crises of minority governments and the repercussions for political stability in settings where the majority, who have voted for losing candidates, are governed by a winning president who has received a minority vote.

The unencumbered and strategic exploitation of the court system and the floor-crossing clause (s 65) by successive minority governments undercuts the need for coalitions. Opposition MPs declare themselves independent in de facto defection to support minority governments in exchange for public appointments or other forms of private return. This substantially weakens the cohesion of opposition parties, and promotes bad governance as it compromises horizontal and vertical accountability.

Cumulatively, the above factors have led to a further decline in internal party cohesion, augmented fragmentation of the party system and increased the volatility of executive-legislative relations, leading to instability in state governance and ultimately undermining democratic consolidation. 
On the basis of the probability that future elections will produce minority governments the lessons of the 1995/1996 UDF/AFORD coalition remain instructive as it served a strategic purpose. Formal coalitions based on mutually acceptable and realistic agreements are the ultimate option for a negotiated post-election political settlement. They enhance the legitimacy of the coalition government, promote trust between coalition partners, diffuse latent conflict and therefore improve state governability and encourage democratic consolidation and party and national cohesion.

\section{POSTSCRIPT}

While the paper on which this article is based was prepared for and presented at the EISA symposium in September 2013 it is being published after Malawi's May 2014 tripartite elections for the president, members of the national legislature and councillors for local government assemblies. A few outcomes of these elections are significant in relation to the question of electoral alliances and the prospects for post-election coalition formations.

Without going into the details of historical regional (ethnic) voting patterns and, indeed, leaving aside the controversies that surrounded the management of the elections and the announcement of the results, the 2014 elections were highly competitive, with 1292 legislative candidates from 17 political parties and 417 who featured on non-partisan (independent) tickets. Twelve candidates stood in the presidential race, only one of them representing the Tisintha Alliance (TA), a formation of six small political parties with George Mnesa, president of the Malawi Forum for Unity and Development (MAFUNDE) as its torch bearer. The other parties were the Congress for National Unity, the Republican Party, the New Republican Party, the MDP and the NUP.

On the other hand, the AFORD and the PP had forged an alliance, with the PP president Joyce Banda as its joint candidate. Notably, the individual and collective support for the Tisintha Alliance was insignificant, as measured by its electoral performance. For example, none of the TA partners was able to secure legislative representation. As Table 8 shows, Mnesa received only $0.2 \%$ of the total valid votes. Importantly, most political parties preferred not to form electoral alliances.

Table 8 shows the comparative share of the vote of eight of the 12 candidates. Each of the other four received $0.2 \%$ or less. Table 8 shows that nearly $63 \%$ of voters did not favour the DPP presidential candidature of Peter Mutharika. The legitimacy of President Mutharikas's government is further challenged by independent MPs, who secured 52 seats $(27 \%)$, while the DPP has $50(27 \%)$, the MCP $48(25 \%)$, the PP $26(13.5 \%)$ and the UDF 14 (7\%). 
Table 8

Share of Votes per Candidate in the 2014 Presidential Election

\begin{tabular}{|l|c|c|}
\hline Candidate & No of Votes & \% of Vote \\
\hline Peter Mutharika (DPP) & 1904399 & 36.4 \\
\hline Lazarus Chakwera (MCP & 1455880 & 27.8 \\
\hline Joyce Banda (PP) & 1056236 & 20.2 \\
\hline Atupele Muluzi (UDF) & 717224 & 13.7 \\
\hline Kamuzu Chibambo (PETRA) & 19360 & 0.4 \\
\hline Mark Katsonga Phiri (PPM) & 15830 & 0.3 \\
\hline John Chisi (UP) & 120848 & 0.2 \\
\hline George Mnesa (MAFUNDE and TA) & 11042 & 0.2 \\
\hline
\end{tabular}

Source: Compiled by author from Malawi Electoral Commission 2014 election results

Given the fact that Malawi has no tradition of formal government coalitions, there are four possibilities for the hung Parliament. First, the MCP, PP and UDF will informally show a common front in opposing or supporting specific legislative proposals. This is likely to result in legislative instability.

Second, the opposition MCP will discernibly fortify its control of legislative business by ensuring that one of its members becomes Speaker, while its president, Lazarus Chakwera, remains leader of the opposition.

A third possibility is that the opposition parties, the MCP, PP and UDF, will seek to dominate portfolio committees, which will probably result in legislative paralysis. The fourth possibility is that the DPP will circumvent the dominance of the opposition by wooing independent MPs with Cabinet appointments and other incentives in exchange for their legislative support for government business.

It is also likely that some opposition MPs will cross the floor to support the DPP in exchange for executive largesse. The number of independent MPs has grown steadily from none in 1994, to 4 in 1999, 39 in 2004, 32 in 2009 and 52 in 2014. There is a similar configuration in the share of seats in the local assembly, as is evident from Table 9. Notably, the combined share of seats among the opposition parties exceeds the combined share of seats held by DPP and independent councillors. 
To avert any future post-election legislative instability arising from the emergence of minority governments and legitimacy challenges, a lasting solution lies in the reform of the electoral law. Specifically, Malawi needs to introduce a two-round system of elections that will ensure that the winning president has at least $50+1 \%$ of the total valid votes (see Aubi 2014). Similarly, tighter anti-floor-crossing legislation and the reintroduction of the recall provision for legislators who change parties will enhance intra party cohesion, thereby reducing party fragmentation.

Table 9

Parties' Share of Local Assembly Seats

\begin{tabular}{|l|c|}
\hline AFORD & 1 \\
\hline NASAF & 1 \\
\hline CCP & 2 \\
\hline INDEPENDENT & 35 \\
\hline UDF & 57 \\
\hline PP & 65 \\
\hline MCP & 131 \\
\hline DPP & 165 \\
\hline Total & 457 \\
\hline Remaining wards & 5 \\
\hline Total wards & $\mathbf{4 6 2}$ \\
\hline
\end{tabular}

Source: Compiled by author from MEC LGE Results, June 2014 


\section{- REFERENCES}

Cassim A. 2014. Zodiak Online, 5 June. 'Civil Society Calls for Electoral Laws Review'. Available at: zodiakmalawi.com/index.php?option=com_cont ent\&view=article\&id=7791:civil-society-calls-for-electoral-laws-review\&catid $=44$ :news-top\&Itemid $=123$

BBC. Available at: www.bbc.co.uk/news/world-africa-17636393

Bertelsmann StiftungTranfromation Index (BTI). Available at: www.bti-project.de / fileadmin/Inhalte/ reports/2012/pdf/BTI\%202012\%20Malawi.pdf

Bräutigam, D. 1999. 'The "Mauritius Miracle": Democracy, Institutions, and Economic Development'. In R Joseph (ed). State, Conflict, and Democracy in Africa. Boulder, CO: Lynne Rienner Press.

Bickers, K \& J Williams. 2001. Public Policy Analysis: A Political Economy Approach. New York: Houghton Mifflin.

Blau, P. 1964. Exchange and Power. New York: John Wiley and Sons.

Cammack, D. 2009. 'The Politics of Chameleon Revisited: The Burden of Malawi's political culture'. In M Ott \& F E Kanyongolo (eds). Democracy in Progress: Malawi's 2009 Parliamentary and Presidential Elections. Zomba: Kachere Books. Cammack, D. 2011. 'Malawi's political settlement in crisis'. Background Paper 04, Africa Power and Politics Programme APPP. London: Overseas Development Institute. Available at: www.institutions-africa.org/filestream/20111110appp-background-paper-04-malawi-s-political-settlement-in-crisis-2011-bydiana-cammack-nov-2011

Chabal, P \& J Daloz. 1999. 'Africa Works: Disorder as Political Instrument'. African Issues. Oxford: International African Institute in association with James Currey, USA: Indiana University Press.

Chaudhury, N C B R. 1969. 'The Politics of India's Coalitions'. The Political Quarterly 40.

Chinsinga, B. 2009. 'Malawi's Political Landscape 2004-2009'. In M Ott \& F E Kanyongolo (eds). Democracy in Progress: Malawi's 2009 Parliamentary and Presidential Elections. Zomba: Kachere Books.

Clark, J \& D Gardinier (eds). 1997. Political Reform in Francophone Africa. Boulder, CO: Westview Press.

Diamond, L. 2010. 'The Rule of Law versus the Big Man'. In L Diamond \& M F Plattner (eds). Democratisation in Africa: Progress and Retreat. Baltimore: The John Hopkins University Press.

Dulani, B. 2004. 'The Elections Under Scrutiny: Process-Results-Lessons'. In M Ott \& B Immink (eds). The Power of the Vote: Malawi's 2004 Parliamentary and Presidential Elections. Zomba: Kachere Book Series.

Dulani, B \& J van Donge. 2005. 'A Decade of Legislative-Executive Squabbles in 
Malawi'. In M A Mohamed Salih (ed). African Parliaments: Between Governance and Government. Palgrave Macmillan.

Dulani, B. 2012. 'The more things change, the more they stay the same: Thoughts on Joyce Banda's first cabinet', 28 April. Available at: ntwee.blogspot. de/2012/04/more-things-change-more-they-stay-same.html

Emerson, R. 1962. 'Power-Dependence Relations'. American Sociological Review 27. Goeke, M \& C Hartmann. 2011. 'The regulation of party switching in Africa'. Journal of Contemporary African Studies 29(3).

Government of Malawi, The. 1999. The Constitution of the Republic of Malawi. Zomba: Government Printer.

Grofman, B. 1996. 'Extending a Dynamic Model of a Protocoalition Formation'. In N Schofield (ed). Collective Decision Making: Social Choice and Political Economy. Kluwer Academic Publishers.

Helmke, G \& S Levitsky. 2004. 'Informal Institutions and Comparative Politics: A Research Agenda'. Perspectives on Politics 2(4).

Huntington, S. 1991. The Third Wave: Democratisation in the late Twentieth Century. London: University of Oklahoma Press.

Hyden, G. 2006. African Politics in Comparative Perspective. New York: Cambridge University Press.

The Icelandic International Development Agency (ICEIDA). 2012. 'Malawi Country Strategy Paper 2012-2016'. Available at: www.iceida.is / media/ pdf/Malawi_ CSP_2012-2016.pdf

ICEIDA. 2013. Available at: www.iceida.is/media/pdf/Malawi_CSP_2012-2016.pdf Janda, K. 2009. 'Laws against Party Switching, Defecting, or Floor-Crossing in National Parliaments: The Legal Regulation of Political Parties'. Working Paper 2, August. Available at: www.partylaw.leidenuniv.nl/uploads /wp0209. pdf

Kadima, D. 2006. 'The Study of Party Coalitions in Africa: Importance, Scope, Theory and Research Methodology'. In D Kadima (ed). The Politics of Party Coalitions in Africa. Johannesburg: Konrad Adenauer Stiftung and EISA.

Kadima, D \& S Lembani. 2006. 'Making, Unmaking and Remaking Political Party Coalitions in Malawi - Explaining the Prevalence of Office-Seeking Behaviour. In D Kadima (ed). The Politics of Party Coalitions in Africa. Johannesburg: Konrad Adenauer Stiftung and EISA.

Kadzamira, Z D. 2000. 'Management of the Electoral Process'. In M Ott, KM Phiri \& N Patel (eds). Malawi's Second Democratic Elections: Process, Problems and Prospects. Blantyre: CLAIM.

Khembo, N. 2004. 'Political Parties in Malawi: From Factions to Splits, Alliances and Coalitions. In M Ott \& B Immink (eds). The Power of the Vote: Malawi's 2004 Parliamentary and Presidential Elections. Zomba: Kachere Book Series. 
Laws, E \& A Leftwich. 2010. 'Riker in the Tropics: The Theory of Political Coalitions 1962 and the Politics of Change in Developing Countries'. Developmental Leadership Program, Concept Paper 02. Available at: www.dlprog.org/ftp/ view / Public\%20Folder/Concept\%20Papers / Riker\%20in\%20the\%20Tropics. pdf

Lembani, S. 2007. 'The Case of Malawi: The Impact of Floor Crossing on Party Systems and Representative Democracy, 2007'. South Africa, KAS Seminar Report No 19.

Lindberg, S. 2010. 'What accountability pressures do MPs in Africa face and how do they respond? Evidence from Ghana'. Journal of Africa 48(1).

Lembani, S. 2011. The Impact of Institutional Arrangements on Intraparty Democracy. Germany: Lambert Academic Publishing GmbH \& Co.

Lembani, S. 2013. 'Institutions and Actors in Legislative Decisions in Africa: Analysing Institutional Contexts and Veto Players in Legislative Decisions in Malawi'. Unpublished thesis submitted to the Ruhr University Bochum, Germany, in partial fulfilment of a $\mathrm{PhD}$ in International Development Studies, 4 September 2013.

Logan, C. \& W Cho. 2009. 'Looking toward the future: Alternations in power and popular perspectives on democratic durability in Africa'. Available at: $w w w . g o o g l e . c o . z a / \# f p=533125 b 8331303 b b \& q=h t t p \% 3 A \% 2 F \% 2 F w w w$. afrobarometer.org\%2Fpapers\%2FAfropaperNo110.pdf

Malawi Electoral Commission. 2014. Final Presidential Result, Malawi Tripartite Election.

Malawi Electoral Commission. 2014. Announcement of the Determination of the Results for Parliamentary and Local Government Elections, 2 June.

Malawi Voice. 21 June 2012. 'DPP Goes to Court over Speaker's Sec 65 Ruling: Speaker Acting As Judge - Nicholas Dausi'. Available at: www.malawivoice.com/ wp-content/uploads/2012/06/Nicolus-Dausi.jpg

Malawi Voice. 22June2012. Available at:www.malawivoice.com/2012/06/22/historyrepeating-itself-nomadic-mps-gag-speaker-with-court-injunction-69950/

Malawi Voice. 19 February 2013. 'DPP, Law Expert Hails Chimunthu's Invocation of Section 65: We Hope Our Petition Will Also See Light of the Day - Chaponda'. Available at: www.malawivoice.com/wp-content/ uploads/2013/02/henryshaba.jpg

Maravi Post. Available at: www.maravipost.com/national/politics/851-defectionbombshell-cassim,-uladi,-phoya-join-joyce-banda\%E2\%80\%99s-pp.html

Matlosa, K \& V Shale. 2013. 'The pains of democratisation: The uneasy interface between elections and power-sharing arrangements in Africa'. Africa Review $5(1)$. 
Mpesi, A M \& R L Muriaas. 2012. 'Food security as a political issue: The 2009 elections in Malawi'. Journal of Contemporary African Studies.

Mpesi, A M. 2011. 'Political Parties and their Manifestos: Inferring Party Policy Positions in Malawi since 1994'. Forum for Development Studies 381.

North, D C. 1990. Institutions, Institutional Change and Economic Performance: Political Economy of Institutions and Decisions. Cambridge: Cambridge University Press. Nyasatimes. Available at: www.nyasatimes.com/

Nyasatimes. 3 July 2013. Available at: www.nyasatimes.com/2013/03/07/malawifull-inquiry-report-on-bingu-wa-mutharikas-death/

Ostrom, E. 1996. 'An agenda for the study of institutions'. Public Choice 48.

Ott, M, \& F E Kanyongolo. Democracy in Progress: Malawi's 2009 Parliamentary and Presidential Elections. Zomba: Kachere Book Series.

Patel, N (ed). 2005. Political Parties: Development and Change in Malawi. EISA Research Report No. 21.

Patel, N, R Tambulasi, B Molande \& A Mpesi. 2007. Consolidating Democratic Governance in Southern Africa: Malawi. EISA Research Report No. 33.

Patel, N. 2008.'The Representational Challenge in Malawi'. In Towards the Consolidation of Malawi's Democracy. Malawi: KAS Occasional Paper No. 11.

Phiri, K. 2000. 'Reflections on Party Ideologies and Programmes'. In M Ott, K M Phiri \& N Patel (eds). Malawi's Second Democratic Elections: Process, Problems and Prospects. Blantyre: CLAIM.

Resnick, D. 2012. 'Two Steps Forward, One Step Back: The Limits of Foreign Aid on Malawi's Democratic Consolidation'. United Nations University World Institute for Development Economic Research UNU-WIDER, Working Paper No. 2012/28. Available at: www.wider.unu.edu/publications/workingpapers/2012/en_GB/wp2012-028/

Riker, W. 1962. The Theory of Political Coalitions. New Haven \& London: Yale University Press.

Scott, J C. 1972. 'Patron-Client Politics and Political Change in South East Asia'. The American Political Science Review 66(1).

Shepsle, K. 2008. 'Rational Choice Institutionalism'. In R A W Rhodes, S A Binder \& B A Rockman (eds). The Oxford Handbook of Political Institutions. New York: Oxford University Press.

UNDP-HDI. hdrstats.undp.org/images/explanations/MWI.pdf

Van de Walle, N. 2001. African Economies and the Politics of Permanent Crisis, 19791999. Cambridge: Cambridge University Press.

Van de Walle, N. 2003. ‘Presidentialism and clientelism in Africa's emerging party systems'. Journal of Modern African Studies 41(2).

Von Neumann, J \& O Morgenstern. 1953. Theory of Games and Economic Behavior. Princeton: Princeton University Press. 
Wyatt, A. 1999. 'The Limitations on Coalition Politics in India: The Case of Electoral Alliances in Uttar Pradesh'. Commonwealth \& Comparative Politics 37(2).

Yashar, D. 1997. 'Introduction'. In D Yashar. Demanding Democracy: Reform and Reaction in Costa Rica and Guatemala, 1870's - 1950's. CA: Stanford University Press.

\section{Interviews}

Boniface Chibwana, Programme Officer, Centre for Multiparty Democracy CMD, Lilongwe. Interviewed 20 August 2013.

Dan Msowoya, Publicity Secretary/former Secretary General, Alliance for Democracy AFORD, Mzuzu. Interviewed 21 August 2013.

Humphrey Mvula, former Director of Campaign and Strategy, United Democratic Front UDF, Blantyre. Interviewed 21 August 2013

Hon. Lingson Belekanyama, MP, Director of Research, Malawi Congress Party MCP, Lilongwe. Interviewed 23 August 2013.

Ian Nankhuni, Publicity Secretary, Peoples Party PP, former Secretary General for Mgwirizano Alliance 1999-2004, Zomba. Interviewed 21 August 2013.

Ms. Chatinkha Nkhoma, MCP, Interviewed 20 September 2013. 